\title{
UNDERSTANDING THE LOGIC OF ORGANIZATIONAL AMBIDEXTERITY
}

ENTENDENDO A LÓGICA DA AMBIDESTRIA ORGANIZACIONAL

Recebido em 15.04.2021 Aprovado em 20.05.2021

Avaliado pelo sistema double blind revien

DOI: https://doi.org/10.12712/rpca.v15i1.49694

\section{Rodrigo Marques de Almeida Guerra}

rmaguerra1@gmail.com

Departamento de Ciências Administrativas da UFSM - Universidade Federal de Santa Maria - Santa Maria, Rio

Grande do Sul, Brasil

https://orcid.org/0000-0003-3900-2663

\section{Maria Emília Camargo}

mekamargo@gmail.com

Programa de Pós-graduação em Administração - Universidade de Santa Maria - Santa Maria, Rio Grande do Sul, Brasil

http://orcid.org/0000-0002-3800-2832

\section{Abstract}

This article aims to investigate the effect of the exploration and exploitation dimensions on profitability and growth in sales by exporting companies. The resource-based view (RBV) theory supported the research findings. The survey involved 132 exporting companies in the state of Paraná/PR. Structural equation modeling was applied with the aid of the AMOS software (Analysis of Moment Structures). The results reinforce the multidimensional concept of organizational ambidexterity, characteristic of exporting companies inserted in a dynamic environment. Thus, it is necessary to develop new organizational skills and competences, aiming to develop structures and mechanisms related to organizational ambidexterity.

Keywords: Organizational ambidexterity. Exploration. Exploitation. Profitability. Sales growth.

\section{Resumo}

Esse artigo tem o objetivo de investigar o efeito das dimensões exploration e exploitation sobre a lucratividade e crescimento em vendas de empresas exportadoras. A visão baseada em recursos (VBR) deu suporte aos achados, tendo sido analisados 132 casos de gestores de empresas exportadoras do estado do Paraná/PR. A modelagem de equações estruturais (MEE) foi aplicada com o auxílio do AMOS (Analysis of Moment Structures). Os resultados reforçam a multidimensionalidade da ambidestria, característica de empresas exportadoras inseridas em ambientes de instabilidade. Ademais, deve-se desenvolver habilidades e competências nos gestores, visando criar estruturas e mecanismos que deem suporte à ambidestria organizacional.

Palavras-chave: Ambidestria organizacional. Exploration. Exploitation. Lucratividade. Crescimento em vendas. 


\section{Introduction}

Exploration refers to the discovery of new knowledge from the learning acquired through processes of variation and planned experimentation, aiming at reaching new markets, new technological competences and new products/services (Gibson \& Birkinshaw, 2004; Gupta et al., 2006; Jansen et al., 2009). Exploitation refers to refinement, increased efficiency, selection, learning through local research, reuse of existing routines and implementation, aiming to meet the needs of current or emerging customers through the existing market (Baum et al., 2000; Gupta et al., 2006; Jansen et al., 2009). The simultaneous use of the concepts exploration and exploitation generates organizational ambidexterity (Raisch \& Birkinshaw, 2008; Simsek, 2009; O’Reilly III \& Tushman, 2013).

The empirical effect of the exploration and exploitation dimensions on the growth in sales and profitability is still neglected (Mudambi \& Swift, 2011; O’Reilly III \& Tushman, 2013), particularly in relation to exporting companies located in countries with emerging economies (Tang et al., 2020). This theoretical-empirical gap (Junni et al., 2013; Campanella et al., 2020) provides opportunities for the emergence of new research, aiming to clarify the effect of relationships based on the theory of RBV (Barney, 1991, 2001a). Bandeira-de-Mello et al. (2016) suggest that quantitative research may assist in the construction of an ambidexterity strategy with a simultaneous focus on international and domestic markets.

From the exposed context, the following research problem was reached: How do the exploration and exploitation dimensions influence the growth in sales and profitability of exporting companies in the state of Paraná/PR? To this end, the objective of this article is to investigate the effect of the exploration and exploitation dimensions on profitability and growth in sales of exporting companies from Paraná/PR. The RBV will support the research findings.

This article is structured in four sections, in addition to the introduction. The second section concerns the theoretical framework. The third section explains the methodological procedures. The fourth section presents the results and discussions. The fifth section, on the other hand, presents the conclusion. future studies and limitations of the research.

\section{Resouce-Based View (RBV)}

In 1959, Edith Penrose published the book The Theory of the Growth of the Firm that influenced several researchers in the consolidation of RBV (Wenerfelt, 1984; Teece, 1982; Barney, 1991, 2001b). Two of her main ideas are anchored on the premise that the company must be seen as a collection of fungible resources; and that, for a company to achieve an ideal expansion standard, it must make use of internal and external resources in a balanced way (Rugman \& Verbeke, 2002). The combination of these concepts generated the Penrose Effect, which proposes that the limit of a company's growth rate interferes with the result of managerial restrictions, emphasizing the importance of behavioral elements and learning in the company's growth processes (Rugman \& Verbeke, 2002).

In the early 1990s, Barney (1991) originated the term RBV under the premise that organizations need to obtain and manage valuable resources (that exploit opportunities and/or neutralize environmental threats), rare (in relation to current competition and potential), inimitable (not to be imitated) and nonsubstitutable (to have no equivalents or substitutes) to obtain sustainable competitive advantage. Another mainstay of the RBV is the heterogeneity of the firm's resources, Barney (1991) supports the idea that resources are distributed heterogeneously among companies. Thus, the concept of sustainable competitive advantage can be achieved as long as the value creation strategy, developed by the company, is not applied by other competitors (Barney, 1991).

After the publication of Barney (1991), several criticisms and contributions were made about RBV (Kor \& Mahoney, 2004; Rugman \& Verbeke, 2002; Peteraf, 1993; Priem \& Butler, 2001). Priem \& Butler 
(2001) criticized the Resouce-Based View when questioning its theoretical conception, the difficulty of being tested empirically and the need for greater contribution by RBV to strategic management. In response, Barney (2001a) publishes the article Is the resource-based "view" a useful perspective for strategic management research? Yes. Where it responds to the criticisms of Priem \& Butler (2001) suggesting points to advance in the theory of the strategic advantage based on resources.

In summary, Barney (2001a,b) states that the primary ideas of the RBV, published in 1991, are tautological, that is, the RBV is considered true by the conceptual repetition over time. Furthermore, he reinforces that RBV can be tested empirically since the variables value, rarity and imitability are parameterized in testable propositions (Barney (2001a). Not satisfied with the various criticisms, ten years after the origin of the RBV. Barney et al. (2001) published the seminal article The resource-based view of the firm: Ten years after 1991 where they generate a re-reading of several publications with a new look at Resouce-Based View, in addition to proposing five fields of study related to RBV, such as: human resource management, economics and finance, entrepreneurship, marketing, international business and strategy (the latter approached in a transversal way to the others knowledge areas).

\section{Organizational ambidexterity and its dimensions}

Organizational ambidexterity is considered an emerging theme involving several areas of knowledge: strategy, learning, technological innovation and organizational design (Lavie et al., 2010; Kouropalatis et al., 2012; Papachroni et al., 2015). The simultaneous use of the exploration and exploitation dimensions has attracted the attention of researchers due to the need to develop new skills, competences and capabilities (Raisch \& Birkinshaw, 2008; Simsek, 2009; O’Reilly III \& Tushman, 2013; Wei et al., 2014).

To achieve ambidexterity. organizations must have a high capacity for operational absorption, that is, refinement and assimilation of new knowledge (Patel et al., 2012), in order to overcome existing deficiencies (Turner et al., 2013). The acquisition of external knowledge from internal resources is considered a critical asset, since it involves the transfer/sharing of knowledge (Dunlap et al., 2014). necessary for organizational learning. The organizational ambidexterity aims to provide a higher level of adaptation to the dynamic environment (Tushman \& O’Reilly III, 1996; Raisch \& Birkinshaw, 2008; O'Reilly \& Tushman, 2008), as it can improve the firm's performance and competitiveness in relation to rivals (Auh \& Menguc, 2005; Raisch et al., 2009; Derbyshire, 2014; Turner et al., 2013).

The academic literature is negligent about the direct effect of organizational ambidexterity on firm performance (He \& Wong, 2004). Recent studies (O’Reilly III \& Tushman, 2013; Fu et al., 2015) state that ambidexterity is the organization's ability to achieve high performance. Therefore, it is necessary for the company to simultaneously reach exploration and exploitation at the level of a business unit for a time horizon (Gibson \& Birkinshaw, 2004; O’Reilly \& Tushman, 2008). Thus, the company's challenge is to investigate the mechanisms of operation and tensions involving the particularities of the dimensions (Tushman \& O’Reilly III, 1996; Gibson \& Birkinshaw, 2004; Lavie et al., 2010; Turner et al., 2013).

Organizational ambidexterity goes beyond the simple balanced and simultaneous use of exploration and exploitation (Raisch \& Birkinshaw, 2008) and specific organizational practices that can investigate improving business management should be identified (Benner \& Tushman, 2003; Mom et al., 2009; Venugopal et al., 2020). The search for the ideal balance between exploration and exploitation can generate excessive loss of resources, being more profitable to reach a magnitude of utilization of the dimensions (Venugopal et al., 2020).

The need for change arises due to the different conflicts and tensions arising from the organizational structure, processes, strategies, capacities and culture of the company, aiming to support the two antagonistic dimensions (March, 1991; He \& Wong, 2004; Jiang et al., 2021). Organizational ambidexterity exists from the coexistence of exploration and exploitation, as it involves different 
characteristics, process complexity and inconsistency for stable environments (Benner \& Tushman, 2003; Simsek et al., 2009).

Organizational ambidexterity can be perceived in a complementary or combined way (Simsek et al., 2009; Koryak et al., 2018; Venugopal et al., 2020). that is, from the interrelated view between the dimensions exploration and exploitation (Papachroni et al., 2015). In this sense, the convergence of these dimensions generates the concept of organizational ambidexterity (He \& Wong, 2004; Cao et al., 2009; Wei et al., 2014).

Although the attributes of organizational ambidexterity are contradictory, it is necessary to develop strategies. structures and processes in a balanced way (Raisch et al., 2009). Therefore. it is necessary to unpack the concept of organizational ambidexterity, aiming at a better theoretical-empirical understanding (Wei et al., 2014).

The simultaneous use of exploration and exploitation can provide greater response power in relation to sales and operating margin (Salvador et al., 2014), sales growth rate (He \& Wong, 2004), development of new products (Wei et al., 2014). superior financial performance (Lubatkin et al., 2006; Simsek, 2009; Venugopal et al., 2020) and organizational performance (O'Reilly III \& Tushman, 2013; Fu et al., 2015).

Companies inserted in an environment conducive to the development of organizational ambidexterity provide better results compared to those that do not have this capacity (Derbyshire, 2014). One of the answers to this may be the organizational learning mechanisms that help organizational ambidexterity (Tushman \& O'Reilly III, 1996). Understanding the company's structural and coordination mechanisms can contribute to a better understanding of the management elements of ambidexterity (Mom et al., 2009).

Jiang et al. (2021) examined the underlying mechanisms that can affect organizational ambidexterity in 206 Chinese manufacturing companies. The results suggest that the flexibility of resources and coordination affect the cognition of senior managers in relation to the exploration and exploitation dimensions. Venugopal et al. (2020) state that the appropriate combination of behavioral strategies of top management corroborate for decision making, information Exchange, innovation and team learning mechanisms.

\section{Paradox of the organizational structure}

Jennings \& Seaman (1990, p. 177) argue that "the organizational structure can restrict the company's ability to respond to new business opportunities". Although the organic structure was a mechanistic progression, it is possible to develop a dual environment capable of bringing together the combination of structures (Farjoun, 2002). Martínez-León \& Martínez-Garcia (2011) point out that, depending on the organizational structure, the company may be able to obtain a higher or lower level of organizational learning.

Organizational ambidexterity can be understood from the analysis of structures and reasons. Previous research (Raisch \& Birkinshaw, 2008; Andriopoulos \& Lewis, 2009; Schilling, 2016) related the dimensions of organizational ambidexterity to mechanistic and organic companies.

The exploitation dimension must be managed from a mechanistic perspective due to the high level of formalization, standardization, specialization and coordination of activities (Schilling, 2016; Chen, 2017; Raisch \& Birkinshaw, 2008). Mechanistic companies need well-defined routines which require a high degree of coordination of actions, aiming at achieving efficient processes, reliability and effectiveness (Schilling, 2016; Chen, 2017). Mechanistic structures require greater rigor as to the specialization and coordination of processes, which hinders the development of innovations (Raisch \& Birkinshaw, 2008; Song \& Chen, 2014). 
The exploration dimension is associated with organic companies that are characterized by a low level of standardization and formalization of activities. aiming to stimulate the gradual discovery of new patterns of specialization and coordination of operations (Raisch \& Birkinshaw, 2008; Song \& Chen, 2014; Chen, 2017). Thus, organic structures seek the progressive formalization of new standards as the processes are recognized and assimilated by the members of the organization (Song \& Chen, 2014; Schilling, 2016; Chen, 2017).

\section{RBV and organizational ambidexterity}

The RBV was originally conceived by Barney (1991) from the conception of valuable, rare, difficult to be imitated or replaced resources that contributes to the achievement of sustainable competitive advantage. The use of idiosyncratic resources and the heterogeneity of the company assist in the development of new organizational capacities (Teece et al., 1997; Barney, 2001a; Teece, 2007).

Organizational capacity is a routine, or set of relevant routines, which when integrated with company flows, supports decision making (Winter, 2003). Therefore, it is necessary to group a wide base of tangible and intangible resources (Teece, 2007), in order to support the deliberate strategies necessary for competition (Chen, 2017), mainly in international markets (Tang et al., 2020).

Little is known how organizational ambidexterity can be applied to companies, especially those with operations in international markets (Bandeira-de-Mello et al., 2016). The difficulty can be understood due to the setback to accommodate opposing operating logic (Raisch et al., 2009; Chen, 2017), especially in markets with a high level of complexity.

In order to make this gap clearer, RBV can be fundamental for the management of tangible and intangible resources (Barney, 2001a), considered essential for the simultaneous development of the exploration and exploitation dimensions (Turner et al., 2013). Knowing how to deal with paradoxical environments and tensions between teams, structures, routines, processes and strategies (Tushman \& O'Reilly III, 1996; Gibson \& Birkinshaw, 2004) can be a critical point for the development of new organizational capacities. Thus, ambidexterity can be a fertile environment for the development of organizational structures that support opposite views, and, at the same time, complementary (Papachroni et al., 2015).

\section{Organizational performance: sales growth and profitability}

Organizational performance is one of the most important multidimensional constructs in the management area (Combs et al., 2005; Richard et al., 2009), being considered a complex and difficult to measure variable, due to the diversity of metrics for its measurement (Behrman \& Perreault, 1982; Venkatraman \& Ramanujam, 1986). In general, performance indicators are measured from a financial and non-financial perspective (Banker et al., 2004; Combs et al., 2005).

Organizational performance is the ability to acquire and assimilate external knowledge, through a new knowledge base (Zahra \& George, 2002). The academic literature indicates some dimensions involving financial performance: profitability, market perception, profitability, operational efficiency, sales growth (Griffin \& Mahon, 1997; Combs et al., 2005; Sharma, 2005; Brito et al., 2009). Previous research (CHEN et al., 2005; Uotila et al., 2009; Surroca et al., 2010) analyzed the financial performance construct in relation to the dimensions of sales growth and profitability (Sharma, 2005; Wiggins \& Ruefli, 2002; Narver \& Slater, 2006).

Little has been done to relate the dimensions of ambidexterity and organizational performance. Raisch \& Birkinshaw (2008) claim that few companies have been able to achieve growth in sales and profits in the long run. Despite this, companies that achieve organizational ambidexterity remain consistently profitable and have the capacity to innovate (Tushman \& O'Reilly III, 1996). 
Bednarek et al. (2016) recognize that the organizational ambidexterity requires greater management of the client portfolio in order to maximize profit and knowledge. Skjølsvik et al. (2007) reveal that profitability is not the only criterion for selecting customers. Fosstenløkken et al. (2003) associate the development of knowledge to companies with dynamic structures, depending on their underlying processes and components.

Based on the above, it is intended to test the empirical relationships between the dimensions of ambidexterity and organizational performance using the following hypotheses:

Hypothesis H1a: There is a positive relationship between exploration and profitability.

Hypothesis H1b: There is a positive relationship between exploration and sales growth.

Hypothesis H2a: There is a positive relationship between exploitation and sales growth.

Hypothesis H2b: There is a positive relationship between exploitation and profitability.

Figure 1 presents the empirical framework and the respective hypotheses.

Figure 1 - Proposed empirical framework

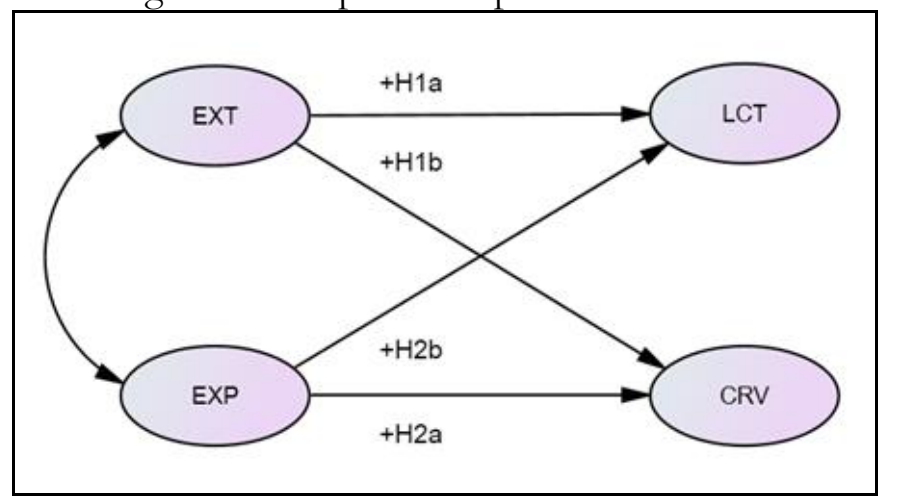

Source: Elaborated by the authors

\section{Methodological procedures}

The research questionnaire (Appendix A) was adapted from Guerra (2017) and was composed of 21 specific questions: exploration (EXT), exploitation (EXP), sales growth (CRV) and profitability (LCT). The sending of the electronic link with the research questionnaire was directed to a population of approximately 1,582 companies in the manufacturing sector in Paraná and which operate in international markets.

The database used was from Federation of Industries of the State of Paraná (FIEP, 2019) and Ministry of Economy, Development, Industry and Commerce (MDIC, 2019). The sample calculation followed the precepts of Hair Jr. et al. (2009) and considered the minimum of five answers per question (105 companies). A pre-test was applied to 78 companies in June 2019, with satisfactory results in relation to descriptive statistics (mean, standard deviation, asymmetry and kurtosis). Small adjustments were made to the questionnaire, aiming to generate a better understanding of the statements.

Subsequently, data collection was carried out between the months of August and October 2019, having obtained a final valid sample of 132 exporting companies, an index considered satisfactory because this research was carried out with organizational managers. For this purpose, two waves were sent to the 
questionnaire link prepared with the help of google forms for the e-mails registered in the database obtained. In some cases, it was necessary to make telephone calls to reinforce the importance of participation by the target audience of the research.

For the multivariate analysis of the data. the normality test was initially performed by means of asymmetry and kurtosis (Pestana \& Gageiro, 2005; Hair Jr. et al., 2009). Once normality was verified, the confirmatory factor analysis (CFA), linear regression and structural equation modeling (SEM) procedures were applied. For this, the statistical software IBM SPSS ${ }^{\circledR}$ (Statistical Package for the Social Sciences) and AMOS (Analysis of Moment Structures) were used. In general, research using SEM requires the help of statistical software due to the high number of samples, complexity for data analysis and number of constructs involved (Schumacker \& Lomax, 2004; Hair Jr. et al., 2009; Kline, 2011).

\section{Results and discussions}

The number of male respondents was 78 , and female, 54 . The companies investigated were classified as small (63), medium (43) and large (26). Within the transformation sector, companies operate mainly in the manufacture of food products (27), rubber and plastic (13), machinery and equipment (16), metal products (except machinery and equipment) (28) and products of non-metallic (21) and mobile (15) minerals. The questionnaire was answered by employees in the areas of human resources (34), production (24), administrative (12), commercial (15), information technology (7) and export/import (40).

The normality of the data is a prerequisite for the application of the SEM (Marôco, 2010). Thus, the asymmetry $(|\mathrm{Sk}|<3)$ and kurtosis test $(|\mathrm{Ku}|<10)$ were performed, having found values that respect the normal distribution (Pestana \& Gageiro, 2005; Hair Jr. et al., 2009). The means and standard deviations were also satisfactory, with no discrepancy in the results (Table 1).

Table 1 - Mean, SD, Alpha, AVE, C.R. and Correlation

\begin{tabular}{lcccccccccc}
\hline Variables & Items & Mean & SD & $\begin{array}{c}\text { Cronbach's } \\
\text { alpha }\end{array}$ & AVE & C.R. & \multicolumn{4}{c}{ Correlation } \\
\hline 1. EXT & 6 & 21.08 & 4.995 & 0.903 & 0.618 & 0.906 & 0.786 & & & 3 \\
2. EXP & 6 & 19.36 & 5.430 & 0.861 & 0.510 & 0.861 & $0.449 * *$ & 0.714 & \\
3. LCT & 5 & 16.72 & 4.197 & 0.832 & 0.504 & 0.835 & $0.607^{* *}$ & $0.595^{* *}$ & 0.710 & \\
4. CRV & 4 & 12.64 & 3.834 & 0.881 & 0.557 & 0.834 & $0.478^{* *}$ & $0.468^{* *}$ & $0.643^{* *}$ & 0.746 \\
\hline
\end{tabular}

Note: $\mathrm{SD}=$ Standard deviation; $\mathrm{AVE}=$ Average Variance Extracted; C.R. $=$ Composite reliability; EXT=Exploration; $\mathrm{EXP}=$ Exploitation; $\mathrm{LCT}=$ Profitability; $\mathrm{CRV}=$ Sales growth; Bold values indicate the square root of AVE.

** p-value $<0.01$

Source: Research data

Table 1 also shows the results of Cronbach's alpha, for each construct they were higher than 0.8 (Hair Jr. et al., 2009). Convergent validity was proven based on the results of the AVE (Average Variance Extracted) $>0.5$, and the C.R. (composite reliability) $>0.8$ (Fornell \& Larcker, 1981). The discriminant analysis was attested by the values of the AVE squared, arranged in bold diagonal (Hair Jr. et al., 2009). The results of the diagonal were superior to those of Pearson's correlation, in their respective lines and columns (Table 1), which proves the discriminant validity.

The state of Paraná/PR is characterized by the presence of companies in the transformation sector that operate in both the domestic (domestic) and foreign (international) markets. For the purpose of this study, it is considered that, the performance of companies in the domestic Market, corresponds to the exploitation construct. Conversely, the sale of products to international markets represents the concept of explotation, according to a theoretical review. 
The results of the hypothesis test can be seen in Table 2. The hypothesis H1a was accepted $(\mathrm{EXT} \rightarrow \mathrm{LCT})$, indicating strength between the variables $(\beta=0.390 ; \mathrm{S} . \mathrm{E}=0.076$; C.R $=5$,159; -value $<0.001)$. The positive and significant relationship between exploration and profitability indicates that exporting companies have made a profit when operating in international markets. This option may be interesting for exporting companies that seek to increase revenue and, consequently, obtain profitability.

Table 2 - Result of the hypothesis test

\begin{tabular}{ccccccc}
\hline Hypothesis & Relationship & Estimate & S.E. & C.R. & p-value & Supported? \\
\hline H1a & EXT $\rightarrow$ LCT & 0.390 & 0.076 & 5.159 & $* * *$ & Yes \\
H1b & EXT $\rightarrow$ CRV & 0.332 & 0.086 & 3.853 & $* * *$ & Yes \\
H2a & EXP $\rightarrow$ CRV & 0.435 & 0.100 & 4.343 & $* * *$ & Yes \\
H2b & EXP $\rightarrow$ LCT & 0.568 & 0.094 & 6.039 & $* * *$ & Yes
\end{tabular}

Note: S.E. $=$ Standard error; C.R. $=$ Composite reliability; $\mathrm{EXT}=$ Exploration; EXP=Exploitation; $\mathrm{LCT}=$ Profitability; $\mathrm{CRV}=$ Sales growth; p-value $=$ Significance level.

**** $\mathrm{p}<0.001$

Source: Research data

The H1b hypothesis was supported $(\mathrm{EXT} \rightarrow \mathrm{CRV})$. The positive and significant effect of the exploration and sales growth relationship was proven $(\beta=0.332$, $\mathrm{p}$-value $<0.001)$. The result allows us to infer that the performance in the foreign market contributes to the growth in sales. Exporting companies with insertion in international markets obtained an increase in sales. particularly in the commercialization of industrialized products, such as: machinery and equipment, electrical machinery and equipment and materials, and rubber and plastic products, to name a few examples.

Despite this, according to information extracted from the website of the Federation of Industries of the State of Paraná (FIEP, 2019), the Brazilian trade balance closed January 2020 with a variation of $19.80 \%$ compared to the same period in 2019. The deficit in the trade balance of Paraná's exports (comparative Jan/Nov 2019/2018) was $-20.21 \%$. This variation may have been a reflection of the low growth in sales in the foreign market (exploration), due to the retraction of the Brazilian economy.

The H2a hypothesis has been confirmed $(\mathrm{EXP} \rightarrow \mathrm{CRV})$. This result indicates that the investigated companies also operate in the domestic market with a positive and significant effect $(\beta=0.435$, $p$-value $<0.001)$. If we compare the result of hypotheses $\mathrm{H} 1 \mathrm{~b}(\beta=0.332$, $\mathrm{p}$-value $<0.001)$ and $\mathrm{H} 2 \mathrm{a}(\mathrm{H} 2 \mathrm{a}: \beta=$ 0.435, p-value $<0.001$ ), it is clear that the greatest intensity of sales growth is in the domestic Market, and not in exports. This fact shows a greater dependence on the investigated companies in relation to the domestic market (exploitation) or less propensity to the foreign market (exploration). However, the positive and significant result, in both dimensions, proves the influence of organizational ambidexterity on the sales growth in relation to the companies surveyed.

The H2b hypothesis was accepted $(\mathrm{EXP} \rightarrow \mathrm{LCT})$. In the perception of the companies surveyed, operating in the domestic market generates greater profit $(\beta=0.568, \mathrm{~S} . \mathrm{E}=0.094, \mathrm{C} . \mathrm{R}=6,039$, $\mathrm{p}$-value $<0.001)$ in relation to the foreign market. It can be seen that the unstable Brazilian economic scenario may have contributed to the performance, search for profit, in the national market, instead of the international market. However, it is worth reinforcing the positive and significant performance of exploration and exploitation capabilities on profitability. This inference proves the strength of the organizational ambidexterity on the profitability of the companies from Paraná in the transformation sector investigated.

Figure 2 presents the results of the proposed framework. It is noticed that the exploration and explitation relationship was performed through covariance. This statistical device was also used in previous research involving SEM, with the purpose of testing empirical models (Kristal et al., 2010; 
Jardon \& Silva, 2017; Shou et al., 2018). The image still reveals a good fit of the tested model: $\chi^{2}=$ 389.297; $\mathrm{df}=183 ; \mathrm{p}=0.000 ; \chi^{2} / \mathrm{df}=2.127$; CFI $=0.905$; GFI $=0.840 ;$ IFI $=0.906$; RMSEA $=0.079$; $\mathrm{P}(\mathrm{RMSEA})<0.001)$.

Figure 2 - SEM result

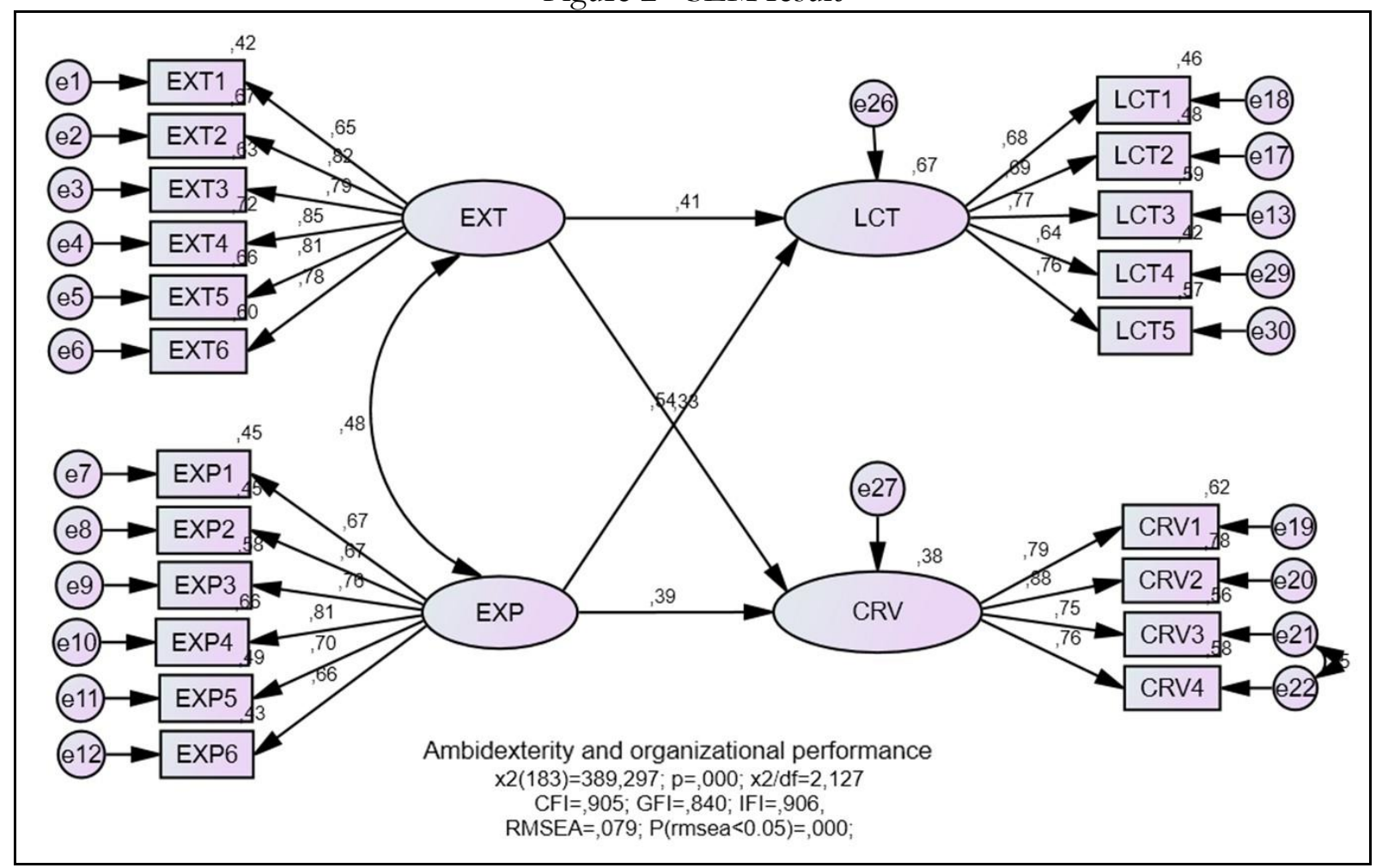

Source: Research data

The covariance was applied because the organizational ambidexterity is a simultaneous concept of exploration and exploitation (Figure 2). By confirming the hypotheses (Table 2), the organizational ambidexterity role in the investigated companies in the transformation sector in the state of Paraná/PR is evidente, and it is not possible to generalize the results to other groups.

At the organizational level, ambidextrous companies have the skills and competence to explore and generate new opportunities with the same dexterity (Lubatkin et al., 2006). Organizational ambidexterity is the capacity that the company has to carry out exploration and exploitation simultaneously (Simsek, 2009; Andriopoulos \& Lewis, 2009). The concepts exploration and exploitation involve complex processes, variables and contingencies, and there are still blind spots for the understanding of their functioning mechanisms due to conflicting and paradoxical challenges (Gupta et al., 2006; Jansen et al., 2009; Lavie et al., 2010).

Exploration is about knowing the new, exploring unknown markets through the use of new technologies and tangible and intangible resources. For that, it is necessary to develop new skills and competences that reinforce the competitive performance in dynamic markets.

The exploitation capability suggests an environment with predictable routines, resources and skills known to the company. Identifying alternatives that generate new opportunities seems to be interesting for long-term competitiveness. Exploitation contributes to the efficiency of local operations, refining current routines for well-known markets. Thus, continuing to learn from existing routines, seeking to further refine information about current customers, are some challenges for organizations with exploitation capabilities. 


\section{Final considerations}

Organizational ambidexterity is an emerging theme in the area of organizational strategy. Its theoretical basis is supported by RBV and dynamic capabilities, despite the need for a specific theory according to the particularities of the theme. The concept of organizational ambidexterity arises from the coexistence of the exploration and exploitation dimensions.

Organizational ambidexterity is understood as the ability of the company to simultaneously explore (new) markets. through the development of (new) skills and competences, based on available tangible and / or intangible resources. The organizational ambidexterity stems from the skill that the company has in the simultaneous use of the two paradoxical dimensions (exploration and exploitation). In other words, organizational ambidexterity will only happen from the coexistence of both dimensions.

The objective of this article was achieved based on the results obtained in the research. The RBV recommends that specific resources, competencies and distinctive capabilities should be combined, aiming at achieving the company's heterogeneity. The singular grouping of tangible and intangible resources can provide returns above the market average. In addition, heterogeneous companies are able to develop mechanisms of isolation in relation to rivals, contributing to the achievement of competitive advantage. However, this advantage can be relative, if the competition environment is moderate, that is, it does not present a high speed of change. For this type of competition, RBV is more suitable. For this reason, we opted for this theoretical basis, and not for dynamic capabilities.

The RBV contributed to a better understanding of the dimensions of exploration and exploitation by helping to create and stimulate environments conducive to the development of organizational strategies aligned with resources, processes, capacities, competences and organizational structures. On the other hand, dynamic capabilities seem to be fertile for the consolidation of organizational ambidexterity. For that, companies must be inserted in a fierce environment of competition, technological turbulence, high risk and uncertainty of return. In organizations that present constant innovation processes, with well-developed learning mechanisms and with speed of absorption, conversion and knowledge transfer, it seems more appropriate to analyze dynamic capabilities, which did not occur in this research.

Organizations inclined to the exploitation dimension are focused on mechanistic structures, that is, with greater rigidity in terms of specialization and coordination of processes, which can hamper the innovation environment. In contrast, the exploration dimension is focused on organic structures with a low gradient of standardization and legitimization of activities. Despite this, organic companies seek to continuously advance in the discovery and validation of new standards of specialization and coordination of activities and processes.

Thus, ambidextrous companies must direct efforts and resources towards the creation of organizational structures that support the exploration and exploitation dimensions simultaneously. This uniqueness requires investments in $\mathrm{R} \& \mathrm{D}$, human resources, use of rare, valuable, difficult to imitate and irreplaceable resources for the composition of the organizational strategy. In addition, it is necessary to constantly improve routines and processes, develop new skills and the ability to manage paradoxical tensions in terms of strategy and organizational structure.

The decision for mechanistic or organic archetypes will directly influence the level of absorption of organizational learning. Mechanistic companies have less capacity to adapt to the external environment, working with structures, routines, processes and activities that already exist and have prior knowledge. Organic companies are exploring the new, unknown markets, with greater dynamics and turbulence, which requires new routines, processes and structures that are able to adapt to the external environment in a more agile way.

In this sense, growth in sales and profitability are dimensions of organizational performance that are 
considered relevant for obtaining financial resources that contribute to the constitution and achievement of organizational ambidexterity. Table 2 confirms the proposed model for companies in the transformation sector in the state of Paraná/PR, since it is possible to perceive the positive and significant influence of the dimensions exploration and exploitation on the variables growth in sales and profitability. This finding can generate theoretical-empirical insights for organizations oriented both for the domestic market and for international trade.

New research should contribute to the theoretical and empirical advancement of organizational ambidexterity and the dimensions of exploration and exploitation in relation to the variables sales growth and profitability. Future research should compare the structure of mechanistic and organic organizations in relation to the dimensions of ambidexterity. Furthermore, studies involving the microfoundations of ambidexterity deserve further investigation in an attempt to advance the proposition of the organizational ambidexterity theory.

In addition, the number of quantitative surveys in other sectors and regions must be expanded, as well as portraying the culture of other countries. Qualitative research is important to understand the underlying effects that may interfere in the exploration and exploitation dimensions, and, consequently, in implications for the area of strategy and entrepreneurship.

At the national level, organizational ambidexterity is a very relevant topic with wide application possibilities in different sectors of activity. However, as Brazil is a country with continental dimensions, organizational and regional cultures can influence the findings of organizational ambidexterity, especially with regard to the behavioral aspects of managers. Ethnic-cultural diversity can be understood as a positive point, as it stimulates innovations, in the dissemination of knowledge and in the learning curve, due to the cultural influence of the participants and teamwork.

The complementarity of the exploration and exploitation dimensions is essential for a better understanding of the behavior of organizational managers, especially in relation to tensions and conflicts between work teams, application of resources, project financing, project risk and facilities infrastructure. The relationship between organizational ambidexterity, and its dimensions, on firm performance is still not clear in the context of Brazilian organizations. Developing new theoreticalempirical models using moderating variables such as risk, culture, gender and/or region can be useful to further clarify the link between the dimensions of organizational ambidexterity and understand the strength of these elements towards the consolidation of a specific theory.

This article presented some limitations, among which two stand out: the study gathered companies from the transformation sector installed in the state of Paraná/PR; the research questionnaire can still be adjusted, in order to make it even more robust; and, the theoretical relationship was anchored in the RBV; thus, future research should broaden the theoretical basis of analysis.

Finally, we would like to thank the PIBIC/UFPA fellows, the participating universities and the researchers involved.

\section{References}

Andriopoulos, C., \& Lewis, M. W. (2009). Ambidexterity : Managing Paradoxes of Innovation ExploitationExploration Tensions and Organizational Ambidexterity: Managing Paradoxes of Innovation. Organization Science Publication, 20(4), 696-717. https://doi.org/10.1287/orsc.1080.0406

Auh, S., \& Menguc, B. (2005). Balancing exploration and exploitation: The moderating role of competitive intensity. Balancing Exploration and Exploitation: The Moderating Role of Competitive Intensity, 58, 1652-1661. https://doi.org/10.1016/j.jbusres.2004.11.007

Bandeira-de-Mello, R., Fleury, M. T. L., Aveline, C. E. S., \& Gama, M. A. B. (2016). Unpacking the 
ambidexterity implementation process in the internationalization of emerging market multinationals. Journal of Business Research, 69(6), 2005-2017. https://doi.org/10.1016/j.jbusres.2015.10.146

Banker, R. D., Chang, H., Janakiraman, S. N., \& Konstans, C. (2004). A balanced scorecard analysis of performance metrics. European Journal of Operational Research, 154, 423-436. https://doi.org/10.1016/S0377-2217(03)00179-6

Barney, J. B. (1991). Firm resources and sustained competitive advantage. Journal of Management, 17(1), 99120. https://doi.org/10.1177/014920639101700108

Barney, J. B. (2001a). Is the resource-based "view" a useful perspective for strategic management research? Yes. In Academy of Management Review (Vol. 26, Issue 1, pp. 41-56). https://doi.org/10.5465/AMR.2001.4011938

Barney, J. B. (2001b). Resource-based theories of competitive advantage: A ten-year retrospective on the resource-based view. Journal of Management, 27(6), 643-650.

Barney, J., Wright, M., \& Ketchen, D. J. (2001). The resource-based view of the firm: Ten years after 1991. Journal of Management, 27(6), 625-641. https://doi.org/10.1016/S0149-2063(01)00114-3

Baum, J. A. C., Li, S. X., \& Usher, J. M. (2000). Making the next move: How experiential and vicarious learning shape the locations of chains' acquisitions. Administrative Science Quarterly, 45(4), 766-801. https://doi.org/10.2307/2667019

Bednarek, R., Burke, G., Jarzabkowski, P., \& Smets, M. (2016). Dynamic Client Portfolios as Sources of Ambidexterity: Exploration and Exploitation Within and Across Client Relationships. Long Range Planning, 49(3), 324-341. https:/ / doi.org/10.1016/j.lrp.2015.12.003

Behrman, D. N., \& Perreault, W. D. (1982). Measuring the Performance of Industrial Salespersons. Journal of Business Research, 10, 355-370.

Benner, M. J., \& Tushman, M. L. (2003). Exploitation, exploration, and process management: The productivity dilemma revisited. Academy of Management Review, 28(2), 238-256. https://doi.org/doi.org/10.5465/amr.2003.9416096

Brito, E. P. Z., Brito, L. A. L., \& Morganti, F. (2009). Inovação e o desempenho empresarial: lucro ou crescimento? RAE - Revista de Administração de Empresas - Eletrônica, 8(1), 1-24. https://doi.org/https://doi.org/10.1590/S1676-56482009000100007

Campanella, F., Del Giudice, M., Thrassou, A., \& Vrontis, D. (2020). Ambidextrous organizations in the banking sector: an empirical verification of banks' performance and conceptual development.

International Journal of Human Resource Management, 31(2), 272-302. https://doi.org/10.1080/09585192.2016.1239122

Cao, Q., Gedajlovic, E., Zhang, H., Cao, Q., Gedajlovic, E., \& Zhang, H. (2009). Unpacking Organizational Ambidexterity: Dimensions, Contingencies, and Synergistic Effects. Organization Science Publication, 20(4), 781-796. https://doi.org/10.1287/orsc.1090.0426

CHEN, M.-C., CHENG, S.-J., \& HWANG, Y. (2005). An empirical investigation of the relationship between intellectual capital and firms' market value and financial performance. Journal of Intellectual Capital, 6(2), 159-176. https://doi.org/10.1108/14691930510592771

Chen, Y. (2017). Dynamic ambidexterity : How innovators manage exploration and exploitation. Business Horizons, 60(3), 385-394. https://doi.org/10.1016/j.bushor.2017.01.001

Combs, J. G., Crook, T. R., \& Shook, C. L. (2005). The dimension of organizational performance and its implications for strategic management research. Research Methodology in Strategy and Management, 2(5), 
259-286. https://doi.org/10.1016/S1479-8387(05)02011-4

Derbyshire, J. (2014). The impact of ambidexterity on enterprise performance: Evidence from 15 countries and 14 sectors. Technovation, 34(10), 574-581. https://doi.org/10.1016/j.technovation.2014.05.010

Dunlap, D., Marion, T., \& Friar, J. (2014). The role of cross-national knowledge on organizational ambidexterity : A case of the global pharmaceutical industry. Management Learning, 45(4), 458-476. https://doi.org/10.1177/1350507613480099

Farjoun, M. (2002). Towards an organic perspective on strategy. Strategic Management Journal, 23(7), 561-594. https://doi.org/10.1002/smj.239

FIEP. (2019). Federação das Indústrias do Estado do Paraná. Cadastro Industrial Do Estado Do Paraná. http://www.fiepr.org.br/ . Acesso em: 18/04/2019

Fornell, C., \& Larcker, D. F. (1981). Evaluating Structural Equation Models with Unobservable Variables and Measurement Error. Joumal of Marketing Research, 18(1), 39. https://doi.org/10.2307/3151312

Fosstenløkken, S. M., Løwendahl, B. R., \& Revang, Ø. (2003). Knowledge Development through Client Interaction : A Comparative Study. Organization Studies, 24(6), 859-879. https://doi.org/https://doi.org/10.1177/0170840603024006003

Fu, N., Ma, Q., Bosak, J., \& Flood, F. (2015). Exploring the relationships between HPWS, organizational ambidexterity and firm performance in Chinese professional service firms. Journal of Chinese Human Resource Management, 6(1), 52-70. https://doi.org/10.1108/JCHRM-09-2014-0029

Gibson, C. B., \& Birkinshaw, J. (2004). The antecedents, consequences, and mediating role of organizational ambidexterity. The Academy of Management Journal, 47(2), 209-226. https://doi.org/10.2307/20159573

Griffin, J. J., \& Mahon, J. F. (1997). The corporate social performance and corporate financial performance debate: Twenty-five years of incomparable research. Business and Society, 36(1), 5-31. https://doi.org/10.1177/000765039703600102

Guerra, R. M. A. (2017). Dynamic capabilities and organizational ambidexterity as mediating variables in the relationship between entrepreneurial orientation and organizational performance [Doctoral dissertation in Administration, University of Caxias do Sul]. https://repositorio.ucs.br/xmlui/handle/11338/3019

Gupta, A. K., Smith, K. G., \& Shalley, C. E. (2006). The interplay between exploration and exploitation in SMEs. Academy of Management Journal, 49(4), 693-706. https://doi.org/10.1108/S1479067X20140000014020

Hair Jr., J. F., Black, W. C., Babin, B. J., Anderson, R. E., \& Tatham, R. L. (2009). Análise multivariada de dados (6th ed.). Bookman.

He, Z. L., \& Wong, P. K. (2004). Exploration vs. exploitation: An empirical test of the ambidexterity hypothesis. Organization Science, 15(4), 481-495. https://doi.org/10.1287/orsc.1040.0078

Jansen, J. J. P., Tempelaar, M. P., Van den Bosch, F. A. J., \& Volberda, H. W. (2009). Structural differentiation and ambidexterity: The mediating role of integration mechanisms. Organization Science, 20(4), 797-811. https://doi.org/10.1287/orsc.1080.0415

Jardon, C. M., \& Silva, A. da. (2017). Intellectual capital and environmental concern in subsistence small businesses. Management of Environmental Quality: An International Journal, 28(2), 214-230. https://doi.org/10.1108/MEQ-05-2015-0085

Jennings, D. F., \& Seaman, S. L. (1990). Aggressiveness of response to new business opportunities following deregulation: An empirical study of established financial firms. Journal of Business Venturing, 
5(3), 177-189. https://doi.org/https://doi.org/10.1016/0883-9026(90)90031-N

Jiang, F., Wang, D., \& Wei, Z. (2021). How Yin-Yang cognition affects organizational ambidexterity : the mediating role of strategic flexibility. Asia Pacific Journal of Management, 1-28.

https://doi.org/https://doi.org/10.1007/s10490-021-09759-9 How

Junni, P., Sarala, R. M., Taras, V. A. S., \& Tarba, S. Y. (2013). Organizational Ambidexterity and Performance. Academy of Management Perspectives, 27(4), 299-312.

Kline, R. B. (2011). Principles and Practice of Structural Equation Modeling (3th ed.). New York: The Guilford Press.

Kor, Y. Y., \& Mahoney, J. T. (2004). Edith Penrose's (1959) Contributions to the Resource-based View of Strategic Management. Journal of Management Studies, 41(January), 183-191. https://doi.org/https://doi.org/10.1111/1467-6486.00174

Koryak, O., Lockett, A., Hayton, J., Nicolaou, N., \& Mole, K. (2018). Disentangling the antecedents of ambidexterity: Exploration and exploitation. Research Policy, 47(July), 413-427. https://doi.org/10.1016/j.respol.2017.12.003

Kouropalatis, Y., Hughes, P., \& Morgan, R. E. (2012). Pursuing “flexible commitment" as strategic ambidexterity: An empirical justification in high technology firms. European Journal of Marketing, 46(10), 1389-1417. https://doi.org/10.1108/03090561211248099

Kristal, M. M., Huang, X., \& Roth, A. V. (2010). The effect of an ambidextrous supply chain strategy on combinative competitive capabilities and business performance. Journal of Operations Management, 28(5), 415-429. https://doi.org/10.1016/j.jom.2009.12.002

Lavie, D., Stettner, U., \& Tushman, M. L. (2010). Exploration and Exploitation Within and Across Organizations. The Academy of Management Annals, 4(1), 109-155. https://doi.org/10.1080/19416521003691287

Lubatkin, M. H., Simsek, Z., Ling, Y., \& Veiga, J. F. (2006). Ambidexterity and performance in small-to medium-sized firms: The pivotal role of top management team behavioral integration. Journal of Management, 32(5), 646-672. https://doi.org/10.1177/0149206306290712

March, J. G. (1991). Exploration and exploitation in organizational learning. Organization Science, 2(1), 71-87. https://doi.org/10.1287/orsc.2.1.71

Marôco, J. (2010). Análise de Equações Estruturais: Fundamentos teóricos, Software \& Aplicações. ReportNumber.

Martínez-León, I. M., \& Martínez-Garcia, J. A. (2011). The influence of organizational structure on organizational learning. International Journal of Manpower, 32(5), 537-566. https://doi.org/10.1108/01437721111158198

MDIC. (2019). Ministério da Economia, Desenvolvimento, Indústria e Comércio. Base de Dados de Empresas Exportadoras e Importadoras. http://www.mdic.gov.br/. Acesso em: 21/05/2019

Mom, T. J. M., van den Bosch, F. A. J., \& Volberda, H. W. (2009). Understanding variation in managers' ambidexterity: Investigating direct and interaction effects of formal structural and personal coordination mechanisms. Organization Science, 20(4), 812-828. https://doi.org/10.1287/orsc.1090.0427

Mudambi, R., \& Swift, T. (2011). Proactive R\&D management and firm growth: A punctuated equilibrium model. Research Policy, 40(3), 429-440. https://doi.org/10.1016/j.respol.2010.10.014

Narver, J. C., \& Slater, S. F. (2006). Efeito da orientação para o mercado sobre a lucratividade da empresa. 
RAE - Revista de Administração de Empresas, 46(2), 61-81.

https://doi.org/https://doi.org/10.1590/S0034-75902006000200013

O'Reilly, C. A., \& Tushman, M. L. (2008). Ambidexterity as a dynamic capability: Resolving the innovator's dilemma. Research in Organizational Behavior, 28, 185-206. https://doi.org/10.1016/j.riob.2008.06.002

O’Reilly III, C. A., \& Tushman, M. L. (2013). Organizational ambidexterity: Past, present, and future. The Academy of Management Perspectives, 27(4), 324-338. https://doi.org/10.1201/b11422-19

Papachroni, A., Heracleous, L., \& Paroutis, S. (2015). Organizational Ambidexterity Through the Lens of Paradox Theory: Building a Novel Research Agenda. The Journal of Applied Behavioral Science, 51(1), $71-$ 93. https://doi.org/10.1177/0021886314553101

Patel, P. C., Terjesen, S., \& Li, D. (2012). Enhancing effects of manufacturing flexibility through operational absorptive capacity and operational ambidexterity. Journal of Operations Management, 30(3), 201-220. https://doi.org/10.1016/j.jom.2011.10.004

Pestana, M. H., \& Gageiro, J. N. (2005). Análise de dados para ciências sociais: a complementariedade do SPSS (4th ed.). Sílabo.

Peteraf, M. A. (1993). The Cornerstones of Competitive Advantage: A Resource-Based View. Strategic Management Journal, 14(3), 179-191. https://doi.org/10.4324/9780203847589

Priem, R. L., \& Butler, J. E. (2001). Is the Resource-Based for Strategic Management Perspective Research? Academy of Management Review, 26(1), 22-40.

Raisch, S., \& Birkinshaw, J. (2008). Organizational Ambidexterity: Antecedents, Outcomes, and Moderators. Journal of Management, 34(3), 375-409. https://doi.org/10.1177/0149206308316058

Raisch, S., Birkinshaw, J., Probst, G., \& Tushman, M. L. (2009). Organizational ambidexterity: Balancing exploitation and exploration for sustained performance. Organization Science, 20(4), 685-695. https://doi.org/10.1287/orsc.1090.0428

Richard, P. J., Devinney, T. M., Yip, G. S., \& Johnson, G. (2009). Measuring Organizational Performance : Towards Methodological Best Practice †. Journal of Management, 35(3), 718-804. https://doi.org/10.1177/0149206308330560

Rugman, A. M., \& Verbeke, A. (2002). Edith Penrose's contribution to the resource-based view of strategic management. Strategic Management Journal, 23(March), 769-780. https://doi.org/10.1002/smj.240

Salvador, F., Chandrasekaran, A., \& Sohail, T. (2014). Product configuration, ambidexterity and firm performance in the context of industrial equipment manufacturing. Journal of Operations Management, 32(4), 138-153. https://doi.org/10.1016/j.jom.2014.02.001

Schilling, M. A. (2016). Strategic Management of Technological Innovation (Sixth Edit). McGraw-Hill Education.

Schumacker, R. E., \& Lomax, R. G. (2004). A beginner's guide to structural equation modeling (2nd ed.). Lawrence Erlbaum Associates: New Jersey.

Sharma, D. S. (2005). The association between ISO 9000 certification and financial performance. International Journal of Accounting, 40(2), 151-172. https://doi.org/10.1016/j.intacc.2005.01.011

Shou, Y., Hu, W., \& Xu, Y. (2018). Exploring the role of intellectual capital in supply chain intelligence integration. Industrial Management \& Data Systems, 118(5), 1018-1032. https://doi.org/10.1108/IMDS06-2017-0285

Simsek, Z. (2009). Organizational ambidexterity: Towards a multilevel understanding. Journal of Management 
Studies, 46(4), 597-624. https://doi.org/10.1111/j.1467-6486.2009.00828.x

Simsek, Z., Heavey, C., Veiga, J. F., \& Souder, D. (2009). A typology for aligning organizational ambidexterity's conceptualizations, antecedents, and outcomes. Journal of Management Studies, 46(5), 864-894. https://doi.org/10.1111/j.1467-6486.2009.00841.x

Skjølsvik, T., Løwendahl, B. R., Kvålshaugen, R., \& Fosstenløkken, S. M. (2007). Choosing to learn and learning to choose: Strategies for client co-production and knowledge development. California Review Management, 49(3), 110-128.

Song, M., \& Chen, Y. (2014). Organizational Attributes, Market Growth, and Product Innovation. Journal of Product Innovation Management, 31(6), 1312-1329. https://doi.org/10.1111/jpim.12185

Surroca, J., Tribó, J., \& Waddock, S. (2010). Corporate responsibility and financial performance: The role of intangible resources. Strategic Management Journal, 31(5), 463-490. https://doi.org/10.1002/smj

Tang, Q., Gu, F. F., Xie, E., \& Wu, Z. (2020). Exploratory and exploitative OFDI from emerging markets : Impacts on fi rm performance. International Business Review, 29(2), 101661. https://doi.org/10.1016/j.ibusrev.2019.101661

Teece, D. J. (1982). Towards an economic theory of the multiproduct firm. Journal of Economic Behavior \& Organization, 3(1), 39-63. https://doi.org/https://doi.org/10.1016/0167-2681(82)90003-8

Teece, D J. (2007). Explicating dynamic capabilities: the nature and microfoundations of (sustainable) enterprise performance. Strategic Management Journal, 1350(August), 1319-1350. https://doi.org/10.1002/smj

Teece, David J, Pisano, G., \& Shuen, A. (1997). Dynamic capabilities and strategic management. Strategic Management Journal, 18(7), 509-533. https://doi.org/10.1142/9789812796929_0004

Turner, N., Swart, J., \& Maylor, H. (2013). Mechanisms for managing ambidexterity: A review and research agenda. International Journal of Management Reviews, 15(3), 317-332. https://doi.org/10.1111/j.14682370.2012.00343.x

Tushman, M. L., \& O’Reilly III, C. A. (1996). Ambidextrous organizations: Managing evolutionary and revolutionary change. California Management Review, 38(4), 8-29. https://doi.org/10.2307/41165852

Uotila, J., Maula, M., Keil, T., \& Zahra, S. A. (2009). Exploration, exploitation, and financial performance: analysis of S\&P 500 corporations. Strategic Management Journal, 30(2), 221-231. https://doi.org/10.1002/smj

Venkatraman, N., \& Ramanujam, V. (1986). Measurement of business performance in strategy research: a comparison of approaches. The Academy of Management Review, 11(4), 801-814.

Venugopal, A., Krishnan, T. N., Srinivas, R., \& Kumar, M. (2020). Finding the microfoundations of organizational ambidexterity - Demystifying the role of top management behavioural integration. Journal of Business Research, 106(August), 1-11. https://doi.org/10.1016/j.jbusres.2019.08.049

Wei, Z., Yi, Y., \& Guo, H. (2014). Organizational learning ambidexterity, strategic flexibility, and new product development. Journal of Product Innovation Management, 31(4), 832-847. https://doi.org/10.1111/jpim.12126

Wenerfelt, B. (1984). A resource based view on the firm. In Strategic Management Journal (Vol. 5, Issue 2, pp. 171-180).

Wiggins, R. R., \& Ruefli, T. W. (2002). Sustained Competitive Advantage: Temporal Dynamics and the Incidence and Persistence of Superior Economic Performance. Organization Science, 13(1), 81-105. 
https://doi.org/https://doi.org/10.1287/orsc.13.1.81.542

Winter, S. G. (2003). Understanding dynamic capabilities. Strategic Management Journal, 995(24), 991-995. https://doi.org/10.1002/smj.318

Zahra, S. A., \& George, G. (2002). The Net-Enabled Business Innovation Cycle and the Evolution of Dynamic Capabilities. INFORMATION SYSTEMS RESEARCH, 13(2), 147-150. https://doi.org/https://doi.org/10.1287/isre.13.2.147.90

\section{Appendix A - Research questionnaire}

\begin{tabular}{|c|c|c|c|c|c|}
\hline \multirow{2}{*}{$\begin{array}{l}\text { Organizational ambidexterity } \\
\text { EXT1: The company accepts requirements that go beyond existing products and } \\
\text { services. }\end{array}$} & \multicolumn{3}{|c|}{$\begin{array}{l}\text { Totally } \\
\text { Disagree }\end{array}$} & \multirow{2}{*}{\multicolumn{2}{|c|}{$\begin{array}{r}\text { Totally } \\
\text { agree } \\
\quad 5 . \square\end{array}$}} \\
\hline & $1 . \square$ & 2. $\square$ & $3 . \square$ & & \\
\hline EXT2: The company invents new products and services. & $1 . \square$ & $2 . \square$ & $3 . \square$ & 4. $\square$ & $5 . \square$ \\
\hline $\begin{array}{l}\text { EXT3: The company is experimenting with new products and services in the local } \\
\text { market. }\end{array}$ & $1 . \square$ & 2. $\square$ & $3 . \square$ & 4. $\square$ & $5 . \square$ \\
\hline EXT4: The company often uses new opportunities in new markets. & $1 . \square$ & $2 . \square$ & 3. $\square$ & 4. $\square$ & $5 . \square$ \\
\hline EXT5: The company regularly uses new distribution channels. & $1 . \square$ & $2 . \square$ & $3 . \square$ & 4. $\square$ & $5 . \square$ \\
\hline \multicolumn{6}{|l|}{ EXT6: The company regularly seeks to approach new customers in new markets. } \\
\hline EXP1: The company often improves the current supply of products and services. & $1 . \square$ & $2 . \square$ & $3 . \square$ & 4. $\square$ & $5 . \square$ \\
\hline $\begin{array}{l}\text { EXP2: The company regularly implements minor adaptations to existing products and } \\
\text { services. }\end{array}$ & $1 . \square$ & 2. $\square$ & $3 . \square$ & 4. $\square$ & $5 . \square$ \\
\hline EXP3: The company improves the efficiency of the offer of products and services. & $1 . \square$ & $2 . \square$ & $3 . \square$ & 4. $\square$ & $5 . \square$ \\
\hline EXP4: The company increases economies of scale in existing markets. & $1 . \square$ & $2 . \square$ & $3 . \square$ & 4. $\square$ & $5 . \square$ \\
\hline EXP5: The company expands services to existing customers. & $1 . \square$ & $2 . \square$ & $3 . \square$ & $4 . \square$ & $5 . \square$ \\
\hline EXP6: Cost reduction of internal $\mathrm{p}$ & $1 . \square$ & $2 . \square$ & $3 . \square$ & 4. $\square$ & $5 . \square$ \\
\hline Organizational performance & \multicolumn{3}{|c|}{\begin{tabular}{|l|l} 
Totally \\
Disagree
\end{tabular}} & \multicolumn{2}{|c|}{$\begin{array}{r}\text { Totally } \\
\text { agree }\end{array}$} \\
\hline CRV1. The company is able to sell products with higher profit margins. & $1 . \square$ & $2 . \square$ & $3 . \square$ & 4. $\square$ & $5 . \square$ \\
\hline CRV2. The company is able to quickly generate sales of new products. & $1 . \square$ & $2 . \square$ & $3 . \square$ & 4. $\square$ & $5 . \square$ \\
\hline $\begin{array}{l}\text { CRV3. The company is capable of producing a high market share in relation to the } \\
\text { territory in which it operates. }\end{array}$ & $1 . \square$ & 2. $\square$ & $3 . \square$ & 4. $\square$ & 5. $\square$ \\
\hline CRV4. The company is able to exceed our sales goals and objectives. & $1 . \square$ & $2 . \square$ & $3 . \square$ & 4. $\square$ & $5 . \square$ \\
\hline LCT1. The company has the capacity to generate profitable sales. & $1 . \square$ & $2 . \square$ & $3 . \square$ & $4 . \square$ & $5 . \square$ \\
\hline LCT2. The greater the market orientation, the greater the company's profitability. & $1 . \square$ & $2 . \square$ & $3 . \square$ & 4. $\square$ & $5 . \square$ \\
\hline LCT3. Sales training increases product marketing, consequently the company's profit. & $1 . \square$ & $2 . \square$ & $3 . \square$ & 4. $\square$ & $5 . \square$ \\
\hline LCT4. Exporting products increases the company's profit. & $1 . \square$ & $2 . \square$ & $3 . \square$ & $4 . \square$ & $5 . \square$ \\
\hline LCT5: Entering new markets increases the company's profit. & $1 . \square$ & $2 . \square$ & $3 . \square$ & 4. $\square$ & $5 . \square$ \\
\hline
\end{tabular}

Source: Adapted from Guerra (2017) 